\title{
BONAPARTIST WORKERS DURING THE SECOND EMPIRE
}

In the nineteenth and twentieth centuries militant and class-conscious European and American workers have generally supported democratic and socialist movements and parties. Workers attracted by antidemocratic and reactionary organizations and regimes have usually come from the dregs of their class, from Marx's famous Lumpenproletariat (true, the leadership has often included disappointed exMarxists). At times, however, this generalization must be qualified. Today, for example, the trade unions that favor Peron in Argentina include the kind of activist worker usually to be found in Social Democratic and Marxist movements. During the final decade of the Second Empire a somewhat similar attitude towards an anti-democratic regime emerged among some French workers. In the i 860's a significant minority of workers, often better educated than the average and with a long record of service to the working class, urged support of the Second Empire and often became devoted followers of $\mathrm{Na}$ poleon III. This article examines the motives and the activities of such Bonapartist inclined workers.

What is even more striking about this Bonapartist workers' movement is that it reached its height during the very years that the working class, as a whole, was turning from toleration of the Second Empire to opposition. The attitude of French workers towards the government of Napoleon III changed several times during the course of the regime. ${ }^{1}$ Although some workers mounted the barricades to resist Louis Napoleon's seizure of power in December I $85 \mathrm{I}$, the attitude of most workers ranged from indifference to benevolent neutrality. Until about 18,8 workers generally approved of the regime, even if not as enthusiastically as members of other classes. The acts of overt opposition by workers usually consisted of symbolic gestures of defiance,

${ }^{1}$ David I. Kulstein, The Attitude of French Workers towards the Second Empire, in: French Historical Studies, Vol. II, No. 3 (Spring, 1962), pp. 356-375. 
such as the singing of forbidden songs. Between about 1858 and 1863 the prestige of the regime among workers reached its maximum. Not only were these the most prosperous years of the Second Empire, but workers also approved of the political reforms of the emerging Liberal Empire and the government's support for the oppressed nationalities of Europe. From about $\mathrm{i} 863$, however, election returns, official and unofficial reports, the press, especially after 1868 when government controls were relaxed, all revealed that the working class had turned against the Second Empire.

It was during these years of mounting opposition to the regime that Bonapartist workers bacame most active. The most militant of such workers were associated with a movement that contemporaries labelled the Palais Royal Group, after the residence of the Prince Napoleon, who, about $\mathrm{i} 860$, became their semi-official patron. ${ }^{1}$

Little is known about the workers who belonged to the Palais Royal Group other than the names and a few details concerning some of the leaders. Contemporaries (and historians of the Second Empire) frequently disagreed on whether particular workers frequented the Palais Royal. The typographical worker, J.-J. Blanc, who was himself suspected of being a follower of the Palais Royal, denounced French workers for their excessive suspicions concerning possible membership in the Palais Royal.2 And as late as 1907 the Socialist historian Albert Thomas still felt called upon to defend Tolain, one of the founders of the French Section of the First International, against the charge that he had been too friendly with the Palais Royal workers, a charge that was frequently made during the Second Empire. ${ }^{3}$

Whether or not Tolain was a member of the Palais Royal Group, there is no doubt that other workers whose views and activities were quite similar to his did belong. Many Palais Royal workers were from the printing trades, a category that, as one printer proudly remarked, led the working class. 4 Thus, one of the most articulate and active members of the Palais Royal Group was the typographical worker A. Coutant, who always insisted that he was a Socialist, even after he rallied to the Second Empire. Before the Revolution of February I 848, Coutant was editor of the worker newspaper, La Ruche populaire; 5

1 Henry Fougère, Les délégations ouvrières aux expositions universelles sous le Second Empire, Montluçon 1905, p. $4^{6}$.

${ }^{2} \mathrm{~J}$. J. Blanc, Les hommes et les souris, in: Almanach de la coopération (1870), pp. 96-97:

"Celui-ci dépend de la préfecture de police, celui-là de tel ministre; cet autre appartient au Palais Royal."

3 Albert Thomas, Le Second Empire, Paris 1907, p. 200.

4 Les délégations ouvrières à L'Exposition universelle de Londres en I 862, Paris I 862, p. 4.

5 Georges Weill, Les Journaux ouvriers a Paris (1830-1870), in: Revue d'histoire moderne et contemporaine, IX (1907-1908), pp. 94, 99. 
a typical article by the editor contrasted the luxury of the wealthy with the poverty of the "martyrs of industry". 1 After February I 848 Coutant became a candidate for the Constituent Assembly on a platform that called for a thorough reorganization of society "to assure the individual of work and the fruits of his labor". ${ }^{2}$ Twenty years later Coutant's ideas remained essentially the same, and he still called himself a Socialist. ${ }^{3}$ Moreover, he refused to admit that a contradiction existed between his socialism and his loyalty to Napoleon III. Another typographical worker, A. Bazin, also an admirer of Napoleon III, protested against the hostility of workers to the Second Empire, and objected to the view that "a good citizen must, above all, be a foe of the regime". ${ }^{4}$ The tin worker Chabaud, with a record of militancy in working class movements, was also a leading member of the Palais Royal Group. I have been unable to learn whether the shoe leather cutter Jacques Durand, a violent anti-clerical and future Communard, actually belonged to the Palais Royal Group, but his praise of Napoleon III sounds much the same as theirs. ${ }^{5}$

The reasons for which the Palais Royal Group and other workers urged confidence in the Second Empire varied. Some such workers were, perhaps, paid agents whose loyalty had been purchased. Others, who remained republicans at heart, favored cooperation with the regime because it existed and seemed likely to exist for the foreseeable future. The political reforms of the I 860's convinced many workers that the Second Empire was moving towards greater liberty. Such workers were also swayed by the government's nationalities policy, particularly actions or statements in favor of the Poles and Italians. A contemporary journalist wrote that the masses were enthusiastic about Garibaldi and his red shirts, and were prepared to "declare war on Russia in order to liberate Poland". 6 In 1859 the procureur général at Lyons reported to the Minister of the Interior that as a result of his Italian policy the Emperor was becoming the "hero" of the working class. ${ }^{7}$

1 "Organisation du travail. Discussion entre le Journal, le Globe et un ouvrier typographe" (Paris I 844). Extrait de la Ruche populaire, by Coutant "ouvrier typographe".

2 Bibliothèque Nationale Le ${ }^{64}$ I 305 , "A M.M. les électeurs du département de la Somme" (Péronne 1848 ). This is an electoral placard.

3 A. Coutant, Propriété et travail association, Paris, 1868, p. r. A pamphlet.

4 A. Bazin, L'opposition, le gouvernement et les classes ouvrières, Paris I865, pp. 5-6.

5 Jacques Durand, Mémoires adressés à la Réunion générale des coupeurs et brocheurs en chaussure de la ville de Paris, Paris n.d. (but after 1864). Georges Duveau, La vie ouvrière en France sous le Second Empire, Paris i 946 , p. 390.

${ }^{6}$ Hector Pessard, Mes petits papiers I 860-1 870, Paris I 887, I, p. IIs.

7 Archives Nationales (hereafter A.N.) $B^{30} 379$, procureur général at Lyons, July 10, 1859. 
The most weighty reason, however, was the belief of pro-Bonapartist workers that the Second Empire had more to offer the working class than other regimes, a belief encouraged by such acts as amendment of legislation forbidding strikes, toleration of the still illegal trade unions, and the aid extended to workers' cooperatives. Many veterans of 1848 , moreover, still recalled the "betrayal" of the February Revolution by the republicans and believed that the opposition to Napoleon III was still more interested in political reform than in the amelioration of the condition of the working class. Coutant attacked the "democratic liberal bourgeoisie" for substituting the word "liberty" for a "serious" program of aid for the people. ${ }^{1}$ Bazin complained that the foes of the Empire sought only more political freedom, and while such freedoms were "precious things", they were not so basic as the material needs of man. ${ }^{2}$ Those individuals who did not lack these material needs believed that "intellectual liberty" was the greatest of values, but for the masses amelioration of their condition, "social progress", was more important. And the Second Empire, based as it was upon universal manhood suffrage, must seek to satisfy the needs of the masses in order to survive.

The fullest statement of the ideology of the Palais Royal Group is a pamphlet, Le Peuple, l'Empereur et les anciens partis (Paris I86I), written in response to an open letter by the Orleanist Duc d'Aumale, which, said the pamphlet, was being distributed among workers. ${ }^{3}$ The pamphlet, written entirely by workers, consisted of an introduction, five articles, and a conclusion. The introduction provided the theme for the entire pamphlet: Although the Second Empire had not yet satisfied the aspirations of workers, there was reason to hope that it would do so in the future. The Duc d'Aumale's letter, on the contrary, rejected these aspirations at the very time that the Second Empire was beginning to act "more and more in the natural and popular interests, internally as well as abroad". 4

The first article by B. V. Viguier, a proof-reader, denounced the political economy of the July Monarchy - a policy "summed up in the formula, laissez-faire, laissez-passer!" The working class, said Viguier, judged governments by their economic policy: "We have had enough

\footnotetext{
A. Coutant, Les candidatures ouvrières, Paris i 869 , pp. 5-6.

2 Bazin, L'Opposition, pp. 4-6.

3 Aumales's pamphlet may be found in Henri d'Aumale, Ecrits politiques (1861-1868), Brussels 1868 . The letter, addressed to the Prince Napoleon, contrasted Louis Philippe's generous treatment of the Bonapartes with Napoleon III's harsh treatment of the Orleanist family. It also attacked the Second Empire's foreign policy.
}

4 Le Peuple, p. 4. 
of speeches; we must also know how to obtain bread." Napoleon III had, on the contrary, demonstrated his sympathy with the needs of the working class, and if progress thus far had been slow and the good intentions of the Emperor had not yet been realized, the fault lay with the many adherents of former regimes who still held high offices. ${ }^{1}$

An article by Chabaud, "Ouvrier ferblantier", attacked the Orleanist monarchy for ignoring the cries of the oppressed nationalities of Europe, and praised the Second Empire for favoring social progress. It urged workers to petition the Emperor for practical and useful reforms:

"We do not believe that Napoleon III, better advised than those who have preceded him, will wait until the Legitimists, Orleanists, and clericals have sown discouragement in all the minds and fomented a senseless disorder, but will rather spontaneously accord the practical reforms desired by the workers."2

A third contributor, Berthélemy, "Typograpbe", also accused the July Monarchy of having done nothing for the nations under foreign rule. Nor had he found in Aumale's letter a single word on the people or "ameliorations in favor of the laboring classes attempted or proposed by the Orleanist family". True, he lamented, the condition of French workers were still miserable, "but we hope that the elected of the nation [Napoleon III] ... will at last listen to our demands". ${ }^{3}$

In an article that interpreted the history of France since 1789 , the bookbinder Alphonse Coquard condemned the selfishness of the bourgeoisie and lauded the Bonapartes, a dynasty which had always been concerned with the welfare of the entire nation. After ending the prerogatives of the nobility, at the time of the French Revolution, the bourgeoisie, by making strikes illegal, revealed that it did not intend to share its newly acquired liberty with the working class. At first the bourgeoisie supported Napoleon I as a bulwark against a return to the Old Regime, but when the Emperor refused to govern in the interest of the bourgeoisie alone, the disappointed middle class abandoned him for the Bourbons. When, however, the Bourbons conferred excessive power upon the nobles and priests, the bourgeoisie incited the people to overthrow the old dynasty and then crowned itself in the person of Louis Philippe. The government of Louis Philippe proved, however, to be too personal for the bourgeoisie, which, seeking reform, once again called the working class to its aid. But the bourgeoisie in 1848

1 "Comment nous n'avons rien à attendre des anciens partis", pp. 5-9.

2 "Ne soyons plus dupes", pp. IO-I4.

3 "Ce qu'ont été les bienfaits orléanistes", pp. I4-19. 
had not anticipated universal suffrage and turned against the Republic which proclaimed it. To the bourgeoisie, Napoleon III then seemed to be a guaranty against revolution, but now that it felt secure and realized, moreover, that the Emperor would never rule in the interests of a single class, the bourgeoisie yearned for a return of the dynasty of its choice, the Orleanists. For this reason it was now trying to create distrust between the people and the government:

"If the bourgeois oligarchy incites the people to distrust the one whom it has elected, this is because it seeks to persuade the people to throw itself once again into the arms of the bourgeoisie, who are the most implacable enemy of the people and of the Emperor. For the people, like the Emperor, desire that the government be the government of all and not of a party."1

The final article, by the printing worker L. Leroy, also drew upon the lessons of French history to convince the working class that it was wise to cooperate with the government. Leroy drew an analogy between the struggle of the working class for the satisfaction of its demands and the struggles of the communes in the twelfth century to gain their freedom. Faced by a powerful feudal nobility, the communes sought the support of the monarchy, which, in turn, welcomed the aid of the towns against the seigneurs and Rome. "Without this union, these two forces would have been absorbed one after the other by feudalism." From this analysis Leroy concluded that the working class should follow the example of the medieval townsmen and cooperate with the government. ${ }^{2}$

The pamphlet closed with an avowal that despite the good intentions of the government, the condition of the working class had deteriorated during the Second Empire. However, the working class itself bore the responsibility for this; first, because of the mistrust with which it received the reforms "granted" (underlined in the text) by the government; and second, because workers did not make their needs known. The pamphlet urged workers to inform the Emperor of their needs in a "firm and respectful voice", and assured them that the people and the Emperor, working together, would in a short time realize the reforms that had been needed for so long a time. ${ }^{3}$

As is indicated by this survey of the Palais Royal pamphlet, the words of praise for the Second Empire by pro-Bonapartist workers were usually accompanied by demands. These demands included the repeal of discriminatory legislation: the ban upon strikes and trade unions,

1 “Qui gagnerait à la Restauration des d'Orléans", pp. 20-33.

2 "Analogie hisrorique", pp. 23-30.

3 "Appel", pp. 31-32. 
of Article $178 \mathrm{I}$ of the Civil Code that provided that in disputes over wages due a worker, in the absence of other evidence, the word of the employer was to be accepted, and of the requirement that workers possess a kind of internal passport, the livret. They also called for such reforms as a shorter work week, the establishment of public employment offices, ${ }^{1}$ and increased government aid for education.

Although such demands were similar to those of republican workers, Bonapartist workers differed from the latter in their belief that the Second Empire would eventually heed the pleas for reform. Their favorite tactic was, in fact, to appeal to Napoleon III to grant the reforms that they desired. Thus, Chabaud urged workers attending a meeting to consider the lack of opportunities for vocational training to bring the problem to the attention of the Emperor, who, when he recognized the need, would certainly provide for more trade schools. ${ }^{2}$ Again, at a public meeting, in 1868 , to protest against the law banning trade unions, Chabaud advised appealing to the Emperor, a method that had succeeded in gaining for workers the right to strike. ${ }^{3}$ Bazin also called upon the working class to end its opposition to the government, and, instead, to inform it of its needs; like Chabaud, he pointed out that this tactic had been successful in the campaign to legalize strikes. ${ }^{4}$ We have already seen that the Palais Royal pamphlet, Le Peuple, l'Empereur et les anciens partis, concluded with a similar message to the working class.

Bonapartist workers also differed from more radical workers in accepting the necessity of gradualism and warning against violence. In i 864, for example, Chabaud urged workers to ignore revolutionaries who called for radical reforms and who sought to stir up class hatred: "In opposition to those who desire a prompt and radical change of our social organization, I want those changes to occur gradually and without shock, for it is only in this way that they will be established upon unshakable foundations." 5

As I have already implied, members of the Palais Royal Group maintained contacts with the working class. They served the Second Empire in a variety of ways, some of which we can only suspect. It is likely that they disseminated the Bonapartist message by word of mouth in the workshops and in workers' organizations, such as the

\footnotetext{
1 Bazin in: Le Pays, Sept. I2, 1865.

${ }^{2}$ Georges Duveau, La Pensée ouvrière sur l'éducation pendant la Seconde République et le Second Empire, Paris 1947, p. I06.

${ }^{3}$ A.N. 45 AP $^{6}$ (dossier 4). "Papiers de Rouher", Nov. 28, 1868. Although this police report refers to a "Chabot", it is undoubtedly Chabaud.

4 Bazin, L'Opposition, pp. $4 \mathrm{ff}$.

${ }^{5} \mathrm{~L}$ 'Opinion nationale, March I 3, 1864 .
} 
mutual aid societies. The law of June 6, 1868, which liberalized legislation on public meetings, enabled foes of the regime, usually republicans and members of the various socialist schools, to attack the regime openly. Bonapartist workers attempted to reply to the critics of the Second Empire at the public meetings that flourished at Paris during the last two years of Napoleon III's reign.

Palais Royal workers also played an important part in the workers' delegations that attended the London Exposition of 1862 . They dominated the Commission ouvrière which organized and directed the delegations from the various crafts; all four officers of the Commission ouvrière (Chabaud was president) were known to belong to the Palais Royal Group. ${ }^{1}$ The main reason that the Second Empire encouraged the worker delegations was economic. The tariff treaty of $x 860$ with England made it vital that French industry become more efficient in order to compete successfully, and the government hoped that the worker delegates and through them other French workers would profit from their observation of English industry. At the same time, public officials recognized that encouragement of the worker delegations had a propaganda value; it showed that the government was concerned with and had confidence in the working class. Palais Royal workers emphasized this point. Coutant, for example, praised the government enthusiastically for making the worker delegations possible: ${ }^{2}$

"Everything in this project is original, down to the slightest circumstance, to the smallest detail. It is, moreover, an act worthy of an epoch of progress and in perfect accord with the fundamental principle of popular sovereignty which is today the indestructible basis of French law and society."

Palais Royal workers also contributed to the propaganda effort of pro-government newspapers by submitting articles and letters to them. Their favorite newspaper was the pro-government L'Opinion nationale, edited by Adolphe Guéroult, a former Saint-Simonian. Guéroult founded his newspaper with the aid of Napoleon III himself and of the Prince Napoleon, who loaned him the necessary capital and intervened with the Minister of the Interior to obtain authorization to publish it. ${ }^{3}$ The Opinion nationale appealed primarily to the liberal bourgeoisie and to better educated workers; it was read, for example,

${ }_{1}^{1}$ Les délégations ouvrières à l'Exposition universelle de Londres en r862, Paris i 862, p. Io.

2 Fougère, Les délégations ouvrières, p. 43.

${ }^{3}$ A.N. $F^{18} 396$, File on L'Opinion nationale. When Guéroult rallied to the Third Republic after the fall of the Empire, the Prince Napoleon angrily demanded repayment of the loan. Article on Guéroult in Larousse, Grand dictionnaire universel du XIXème siècle. 
by some Parisian members of the First International. ${ }^{1}$ The propaganda in L'Opinion nationale differed from that to be found in other progovernment newspapers in that, unlike the latter, it did not praise the Empire unreservedly; at times, in fact, its criticism of the Second Empire was just as sharp as that of the opposition press. Guéroult's newspaper differed fundamentally, however, from opposition newspapers in its insistance that social progress could be made under Napoleon III. This was also the position of the worker contributors to L'Opinion nationale, for example Coutant, who from 1862 wrote frequently for the newspaper. Coutant's articles had a few kind words for the government and more often for Napoleon III, but usually they called for some reform. However, the mere fact that a newspaper known to be pro-government printed articles and letters urging measures in behalf of workers seemed a hopeful sign.

Palais Royal members often monopolized a regular column for workers' letters established in 1865 by the government newspaper Le Pays. Chabaud, Coutant, and Bazin contributed regularly to the Chroniques ouvrières, as the column was called. Although such letters often lauded the measures already taken to aid the working class, their real value as propaganda was that they showed that the government realized the need for additional reforms and that it wanted to hear the views of workers. The issue of Le Pays (May 30, 1865) which announced the Cbroniques ouvrieres stressed that it was in the interest of the working class to cooperate with the government: "We are profoundly convinced that given the situation of the working class today, it cannot improve its condition without the support and the aid of the state."

The most ambitious propaganda effort of the Palais Royal group was, however, the publication of a series of pamphlets for workers, the Brochures ouvrières. The pamphlets, printed by Dentu, who was frequently referred to as the "Emperor's printer" during the Second Empire, appeared in a similar format and sold for the low price of thirty centimes. I have been unable to find statistics on the number of Brochures ouvrieres printed or sold, but frequent references to them by contemporaries and their relative abundance in French libraries indicate that they had a wide circulation. The pamphlets were not only Imperialist propaganda. In almost all of them praise for the regime was accompanied by pleas for further reforms to aid the working class, and in many of them the praise was almost perfunctory. Some of the pamphlets called for broad reforms that interested the working class

1 Duveau, La pensée ouvrière, p. 312. 
as a whole. ${ }^{1}$ Others discussed specific reforms, ${ }^{2}$ or the grievances of particular crafts. ${ }^{3}$

But even the pamphlets written to urge a specific reform or to defend the interests of a particular craft rarely failed to say something good about the regime or Napoleon III (this was, of course, frequently good "public relations" as much as propaganda). One Brocbure ouvrière referred to the Emperor as the author of that "excellent book, the Extinction du paupérisme", and "the liberator of Italy".4 Another pamphlet urging the government to aid needy and unemployed workers cited the reforms already granted by the Emperor as evidence of the "liberalism of his government", and of the fact that "privilege had had its day"; it expressed the hope that France would soon see "the realization of the wish so dear to the heart and mind of the Prince Louis Napoleon Bonaparte: L'EXTINCTION DU PAUPERIS$M E$ ". ${ }^{5}$ A Brochure ouvriere called the attention of the royal couple to the deplorable conditions that prevailed in homes for the aged, a subject, said the pamphlet, sure to interest rulers who were so concerned with the well-being of the people. The pamphlet also praised the Emperor for maintaining the gains made by the working class in $1848 .^{6}$

Although many pro-Bonapartist workers later rallied to the Third Republic and some joined the socialist movements of the last decades of the nineteenth century, a few remained loyal to Bonapartism even after the fall of the Second Empire. In fact, the harsh repression of the Paris Commune and the persecution of the Communards led some of the workers who had participated in the insurrection to gaze nostalgically back upon the Second Empire. The worker poet Lapointe dreamed of a socialist state under a restored Napoleon III. ${ }^{7}$ Albert Richard, leader of the First International at Lyons between I 866 and I871, and an exile after the Commune, agitated for a return of Napoleon III, insisting that a Bonapartist Empire would do more

${ }^{1}$ Le Peuple, l'Empereur et les anciens partis; A l'Empereur. Les cahiers populaires I \& II, Paris $186 \mathrm{r}$.

${ }^{2}$ L'Organisation des travailleurs par les corporations nouvelles, Paris 186 i ; A l'Empereur Napoléon III, manifeste des ouvriers, Paris n.d.

3 Voeux et besoins des ouvriers corroyeurs, Paris 1862 ; Coutant, Du salaire des ouvriers compositeurs, Paris I86I; Des intérêts typographiques devant la conférence mixte. Des maîtres imprimeurs et des ouvriers compositeurs, Paris I $86 \mathrm{I}$.

4 Voeux et besoins des ouvriers corroyeurs, pp. $21,23$.

${ }^{5}$ A l'Empereur Napoleon III.

- A l'Empereur. Les cahiers populaires I, pp. 8, 2I: “Aujourd'hui, en politique, le peuple est l'égal de la bourgeoisie, puisque, grâce aux conquêtes de février, maintenues par l'Empereur, il nomme les députés au Corps législatif, les membres des conseils municipaux et des conseils généraux."

${ }^{7}$ Duveau, La pensée ouvrière, p. 296. 
for the working class than any other regime, including the Republic. ${ }^{1}$ At Napoleon III's funeral, in 1873, a workers' delegation paid its respects to the ruler; one worker carried a wreath with the words, "Souvenirs et regrets des ouvriers de Paris à sa Majesté l'Empereur Napoleon". ${ }^{2}$ A sign of the depth of Bonapartist sentiment among some workers was that as late as 1878 striking miners at Anzin raised the cry of "Vive Napolên IV!"3

1 Albert Richard and Gaspard Blanc, L'Empire et la France nouvelle, appel du peuple et de la jeunesse à la conscience française, Brussels $x 8_{72}$. True, Richard soon renounced Bonapartism and became a socialist.

2 Thomas W. Evans, Memoirs of Dr. Thomas W. Evans. The Second Empire, New York r 905, p. sor. The American Evans was the Empress's dentist.

' Daniel Halévy, La République des ducs, Paris 1937, p. 335. Other miners responded, however, with shouts of "Vive la République!". 